\title{
NATURAL GEOGRAPHY AND DISPERSE URBAN DEVELOPMENT. RESIDENTIAL DEVELOPMENTS ON MOUNT MONTJUÏC IN BARCELONA IN THE NINETEENTH CENTURY
}

\author{
Jordi GOMIS $^{1}{ }^{1}$, Ramon RIPOLL ${ }^{2}$, Carlos TURÓN ${ }^{3}$ (D), Miquel-Àngel CHAMORRO ${ }^{4}$
}

DOI: $10.21163 /$ GT_2020.152.12

\begin{abstract}
:
With regard to the nineteenth century, planned extension projects have been widely studied whereas semi-planned urban development plans have been researched rather more vaguely. The number of instances, situations and solutions of this latter type of disperse urban development, and its notable impact on current times, is the reason behind this research into twelve semi-planned residential developments on Mount Montjuïc in Barcelona between 1864 and 1868. They are examples of suburban settlements that represented a new way of hybrid living between the city and the countryside and, therefore, an attempt to come halfway between regular, repetitive urban planning and the natural, irregular, free reality forced by the underlying topography. This research article provides material for reflection on the history of urban planning linked to the natural environment, and above all on the contemporary origin of a new relationship between predictable (reversible) urban planning and the unpredictable (irreversible) natural geography in the definition of the suburban landscape.
\end{abstract}

Key-words: Geography, City Planning, Topography, Landscape.

\section{INTRODUCTION}

In the city of Barcelona, as in many other European cities that underwent great industrial development in the nineteenth century, there are many examples of urban growth bordering between regular planning and irregular spontaneity. Of interest in this regard are areas of expansion that interrupt regularity due to pre-existing features that persist over time and have been studied in depth (González, 2008) or consolidated irregular alignments quite unlike the repetitive grid (Sica, 1981). During this period, also interesting is the growth of peripheral settlements of Barcelona (Sarrià, Horta, Sant Gervasi, Sant Martí de Provençals, les Corts, Sants, etc.) characterized by their planning and spontaneity (Serra, 1995); a peripheral ring defined by partially repetitive planning and imperfect continuity (Solà-Morales, 1993). Such examples can be described as disperse planning that enables the emergence of both singular social forms and genuine cultural spaces (Solà-Morales, 1993). Such situations result from the advantages and disadvantages of urban planning that is sometimes a consequence, and others in advance of the events it seeks to control (Benevolo, 1992).

The aim of this study is to examine the concept of disperse urban planning which is on the border between planning and spontaneity, especially due to its direct implications on a social level directly solving problems of housing migratory movements that took place during the 19th century. Culturally, highlighting society's great ability to adapt to the most varied processes of urban development (García, 2016) and especially at the level of the individual and collective imaginary, identifying the

\footnotetext{
${ }^{1,3}$ Universitat Rovira i Virgili, Av. Països Catalans 26, 43007-Tarragona, Spain, jordi.gomis@urv.cat,carlos.turon@urv.cat

${ }^{2,4}$ Universitat de Girona, C/Maria Aurèlia Capmany 61, 17003-Girona, Spain, ramon.ripoll@udg.edu,mangel.chamorro@udg.edu
} 
roots shared with the geographic location. The result is the emergence of a partial urban design, a combination of the rational model and the organic model or between determinate urban planning and the indeterminate "collage" (Julián, 1988). A kind of heterodox growth that over the years, as has been shown, is increasingly recognized, accepted and valued as an alternative to more orthodox, rigid, regular and radical growth due to being totally planned "a priori" (Rowe et al., 1998). These examples are more open and interesting for the study of their rich, complex urban meanings (Choay, 1965), and of the growing importance of geography as a method of analysis between city and countryside (Cassassas, 1977). Also, of the interrelated, and not simply juxtaposed uses, which interact continuously through space and time (Capell, 2001). Forms of growth that enable the emergence and renewal of unlimited geographical and urban meanings (De Castro, 1997).

In the case of the city of Barcelona, during the second half of the nineteenth century, the population quadrupled in sixty years (from 183,787 inhabitants in 1857 to 710,337 inhabitants in 1920). It is interesting to note that some of these people, though few, occupied the urban periphery of the Eixample (Cerdà, 1968) district with new, different settlement patterns. From all of these diverse and relatively interesting examples, we have selected actions based on more regular typological proposals located in places of natural, rather irregular geography. They are the initiatives of private developers, which gained the acceptance of the owners of the land (or vice-versa), and obtained the approval of the military authorities to build within the militarized zone of Mount Montjuïc. Thus, a hypothesis is posed, based on the rise, already in the nineteenth century, of a kind of disperse growth of small urban districts in the middle of the countryside that entails a different relationship between architecture (repetitive types), planning (organization of spaces) and geography (human occupation of natural habitats). With regard to our methodology, field data were obtained from building permits in the archives of military engineers of the General Archive of the Crown of Aragón (ACA). Each application consists of the report, the justification, location and plot plans, as well as the layout, section and front elevation of the dwellings. Our working method is based on comparing this theoretical information with the actual geographical features, such as topography, the road network and the cadastral properties of Mount Montjuïc at the time. The aim is to investigate how disperse planning proposes a way of life between the regularized functionality of architectural typologies and, at the same time, the rational morphology of planning with the irregularities and naturalness of rural geography. In all likelihood, the creation of these fragmented districts does not involve situations of social disunity, segregation or deactivation, quite the opposite. So, one should consider that these examples, like so many other similar ones throughout Europe during this period, represent clear attempts to anticipate the new geographical, social and cultural relationship between countryside and city, which was, as we all know, to develop significantly in the twentieth century.

\section{HISTORICAL BACKGROUND}

It should be recalled that Mount Montjuïc in Barcelona, as a strategic military area and of social control over the city, the port and the plain of Barcelona, is dominated by the Castle. A modern fortress, built according to the principles of geometry, mathematics and defence of Sébastien Le Prestre de Vauban, which at the same time, in the eighteenth and nineteenth centuries, delimited a military security zone of 1,500 varas (equivalent to 1,253 m) from all is surroundings. It should also be said that this military protection zone was privately owned but subject to rigorous military servitude. This rule allowed only the use of the land without any building intervention, unless special permission was given, such as for quarrying, the building of retaining walls or the construction of buildings for very well justified reasons. In the latter case, the buildings had to be on just a single level and made of easily demolishable materials, should the military so rule. This forced buildings of less than $3.5 \mathrm{~m}$ in height with walls $14 \mathrm{~cm}$ thick or less, and structural pillars no greater than $56 \mathrm{~cm}$ across. Thus, a special geographical ring was created that was defined by both military/defensive standards and by the natural/agricultural customs and residential-manufacturing activities.

Regarding building permits, residential-manufacturing activities specifically accounted for 220 licences granted between 1740 and 1913. Initially, the granting of permits for exploitation and 
construction was scarce and as the years went by, it increased in number and importance. It can also be seen that the period with the greatest number of permits validated comes above all during the second half of the nineteenth century and particularly during the 1860 s. It should also be noted that residential permits are most numerous, accounting for $50 \%$ of the total (109 permits) including those for the building of single-family dwellings houses (52 permits), groups of two and five dwellings ( 24 permits), and clusters of more than five dwellings ( 23 permits). Thus, the construction of a total of 784 dwellings was granted (Table 1). Of these, 12 examples of one-off developments were selected (between 6 and 87 houses). This was performed using criteria of diversity and clarity of the information presented and especially their location.

Table 1.

Building permits for Mount Montjuïc in Barcelona (1740-1930).

\begin{tabular}{|c|c|c|c|c|c|c|c|c|c|c|c|c|}
\hline & $\begin{array}{l}\text { BUILDING } \\
\text { PERMIT }\end{array}$ & $\begin{array}{c}\text { TOTAL } \\
\text { PERMITS }\end{array}$ & $<1850$ & $1851-1860$ & $1861-1870$ & $1871-1880$ & $1881-1890$ & $1891-1900$ & $>1900$ & $\begin{array}{c}\text { TOTAL } \\
\text { DWELLINGS }\end{array}$ & $\begin{array}{l}\text { FIRST } \\
\text { DATA }\end{array}$ & $\begin{array}{l}\text { LAST } \\
\text { DATA }\end{array}$ \\
\hline 1 & VARIOUS & 71 & 9 & 8 & \begin{tabular}{|l|}
16 \\
\end{tabular} & 4 & 8 & 7 & 19 & 1 & 1740 & 1913 \\
\hline 2 & SINGLE FAMILY & 52 & I & 4 & 19 & 10 & 1 & 17 & 2 & 52 & 1851 & 1908 \\
\hline 3 & $\begin{array}{l}\text { MULTI-FAMILY } \\
(2 \text { to } 5 \text { dwellings) }\end{array}$ & 24 & 1 & 1 & 19 & 2 & 1 & 1 & 1 & 69 & 1849 & 1891 \\
\hline 4 & $\begin{array}{l}\text { MULTI-FAMILY } \\
\text { (>5 dwellings) }\end{array}$ & 23 & 1 & 1 & 23 & 1 & 1 & 1 & 1 & 513 & 1864 & 1867 \\
\hline 5 & ROUNDABOUTS & 17 & 1 & 1 & 1 & 1 & 5 & 2 & 10 & 150 & 1884 & 1905 \\
\hline 6 & \begin{tabular}{|l|} 
TILING \\
\end{tabular} & 14 & 1 & 2 & 9 & 3 & 1 & 1 & 1 & 1 & 1856 & 1880 \\
\hline 7 & FACTORY & 7 & 1 & 2 & 4 & 1 & 1 & 1 & 1 & 1 & 1858 & 1877 \\
\hline 8 & HOUSE & 4 & 1 & 1 & 2 & 1 & 1 & 1 & 1 & 1 & 1864 & 1899 \\
\hline 9 & LIVESTOCK PENS & 4 & 1 & 1 & 3 & 1 & 1 & 1 & 1 & 1 & 1830 & 1868 \\
\hline 10 & QUARRY & 3 & 1 & 1 & 1 & 1 & 1 & 1 & 1 & 1 & 1880 & 1902 \\
\hline 11 & PLOTS & 1 & 1 & 1 & 1 & 1 & 1 & 1 & 1 & 1 & 1877 & 1877 \\
\hline & TOTAL & 220 & 12 & 17 & 95 & 21 & 14 & 29 & 32 & 784 & & \\
\hline
\end{tabular}

In all these permits, a strict protocol is followed:

- Request for the building permit: The owner of the property or developer requests building permission from the Queen by means of a written report and plans to a scale of $1 / 200$ and $1 / 100$ (measured in meters and others also in meters and spans).

- $\quad$ Report by the military engineers: The chief engineer drafts a report following military regulations and a map of the exact location of the building work on the mount to a scale of 1/10,000 (measured in meters).

- Granting by the military governor: The military governor justifies the suitability or not of granting a building permit in accordance with military regulations.

- Monitoring of the works: The military engineers ensure compliance with the permit granted.

This information allows deducing the following general aspects. First, the technical requirements of the engineers that force the private owners to render clear, accurate plans. Their authorship, though not reflected in these drawings, evidently corresponds to master builders and architects given their preciseness in defining the property, the geomatization of space, the layout of the houses, the careful style of the facades, etc. Secondly, the profitability of these developments means that their goal is to make financial profit from the rural land that was predominantly not used by its owners. Therefore, the persons applying for permission are always the most entrepreneurial proprietors of Mount Montjuïc. And, thirdly and finally, the high architectural functionality of the developments aims to meet the needs of the real estate market for townhouses, such as hygiene, sanitation, good internal organization, the large size of the outdoor patio, and so forth. Thus, sanitation and functionality are equally important and totally complementary features. Of these developments carried out during this period, twelve have been studied whose features and location were considered particularly characteristic (Fig. 1). 


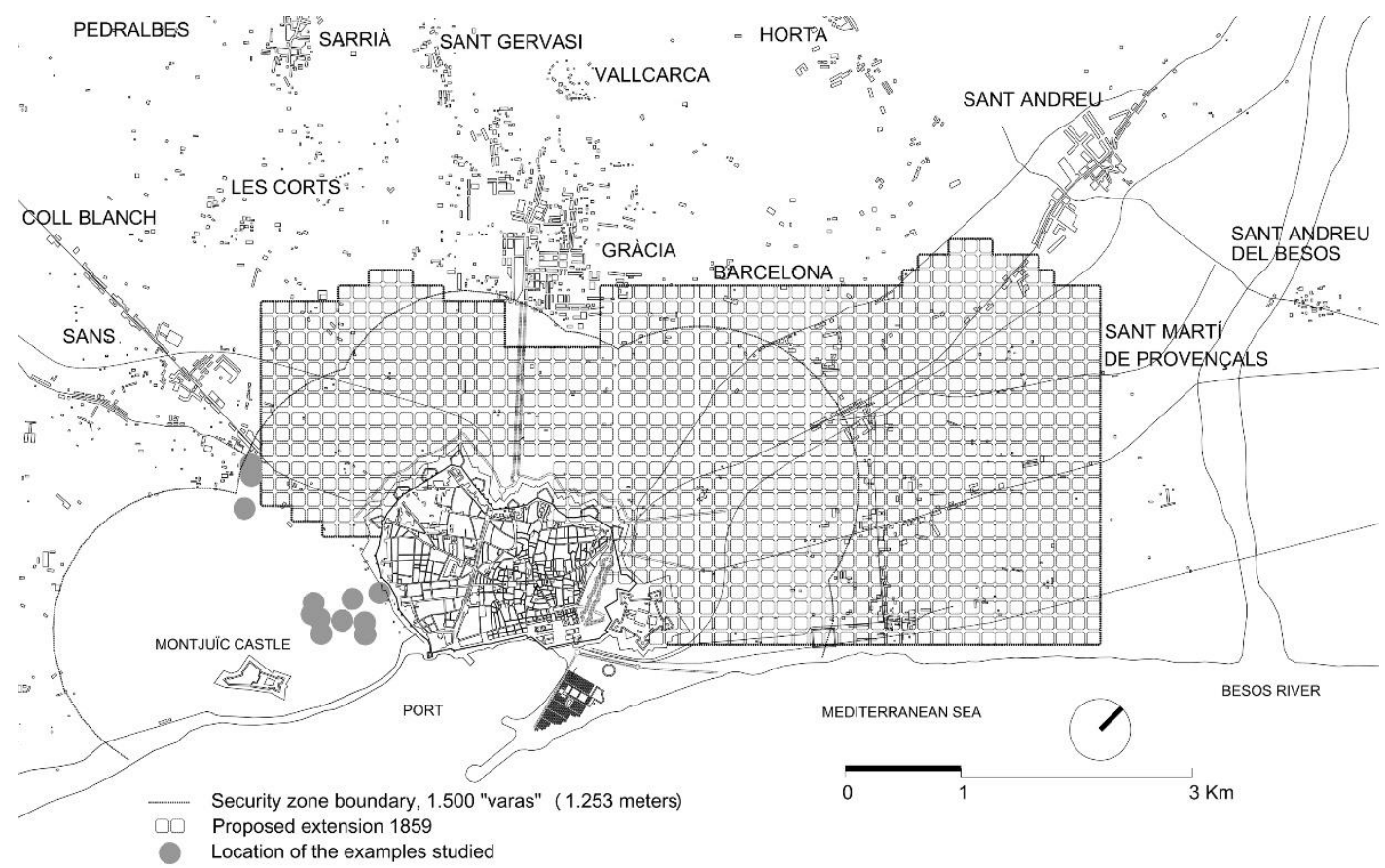

Fig 1. Location map of the 12 developments of Mount Montjuïc of Barcelona (1864-1867).

(Drawing by R. Ripoll, private archive, 2019)

\section{SITE TOPOGRAPHY AND GEOGRAPHY}

The study of the topography of Mount Montjuïc in Barcelona reveals that it is at an elevation of approximately $174 \mathrm{~m}$ higher than the city of Barcelona at its highest point $(+184 \mathrm{~m}$ above sea level) compared to the city flatlands $(+10 \mathrm{~m}$ above sea level). This relatively large difference in altitude gives rise to different gradients according to the aspects of the mount. The steepest slopes are located on the eastern aspect facing the sea (from 30 to 200\%), normal slopes are located on the north, or cityfacing slope (15 to $24 \%$ ), while the gentlest gradients are found facing the west and south in the direction of the inland plains ( 5 to $22 \%$ ). This results in a rugged geography with sporadic natural crags (in the area of the port and the sea) and artificial cuts caused by quarries and torrents of water (from the Trobada and dels Jueus fountains, etc.). Such diversified geography that connects the city by road and tracks with small fields of crops (Beltran orchards, scarcely productive crops, etc.) and the various private properties. The result is an austere, heterogeneous and fragmented topography (Fig. 2). An analysis of the ownership structure (according to the cadastre of 1851) allows us to observe a very important property division. Let us recall that a proprietor can own at the same time one or several cadastral units, which, in turn, can be joined or separated by short or long distances. However, this study demonstrates the advantages of owning a rural property in Mount Montjuïc due to its proximity to the city of Barcelona, while its negative aspects include the limitations of its rugged geography (steep, rocky area) and especially the burden of military jurisdiction (limited uses and buildings). Furthermore, the surface area of each of the average-sized properties is of around 10,000 $\mathrm{m} 2$ (specifically between 8,000 and $12,000 \mathrm{~m} 2$ ). The smaller properties cover an area of approximately $2,000 \mathrm{~m} 2$ (properties of less than 1,800 $\mathrm{m} 2$ are scarce), and the largest properties are approximately $20,000 \mathrm{~m} 2$ (properties of over $30,000 \mathrm{~m} 2$ are scarce). Their perimeters range from rectangular to irregular trapezoidal in shape. In most of the dwellings studied (examples 1 to 8 ) the cadastral unit of the property generally coincides with the developed unit. However, in the most important interventions (examples 9 to 12) it can be deduced that the size of the developed unit requires the union of several cadastral units. 


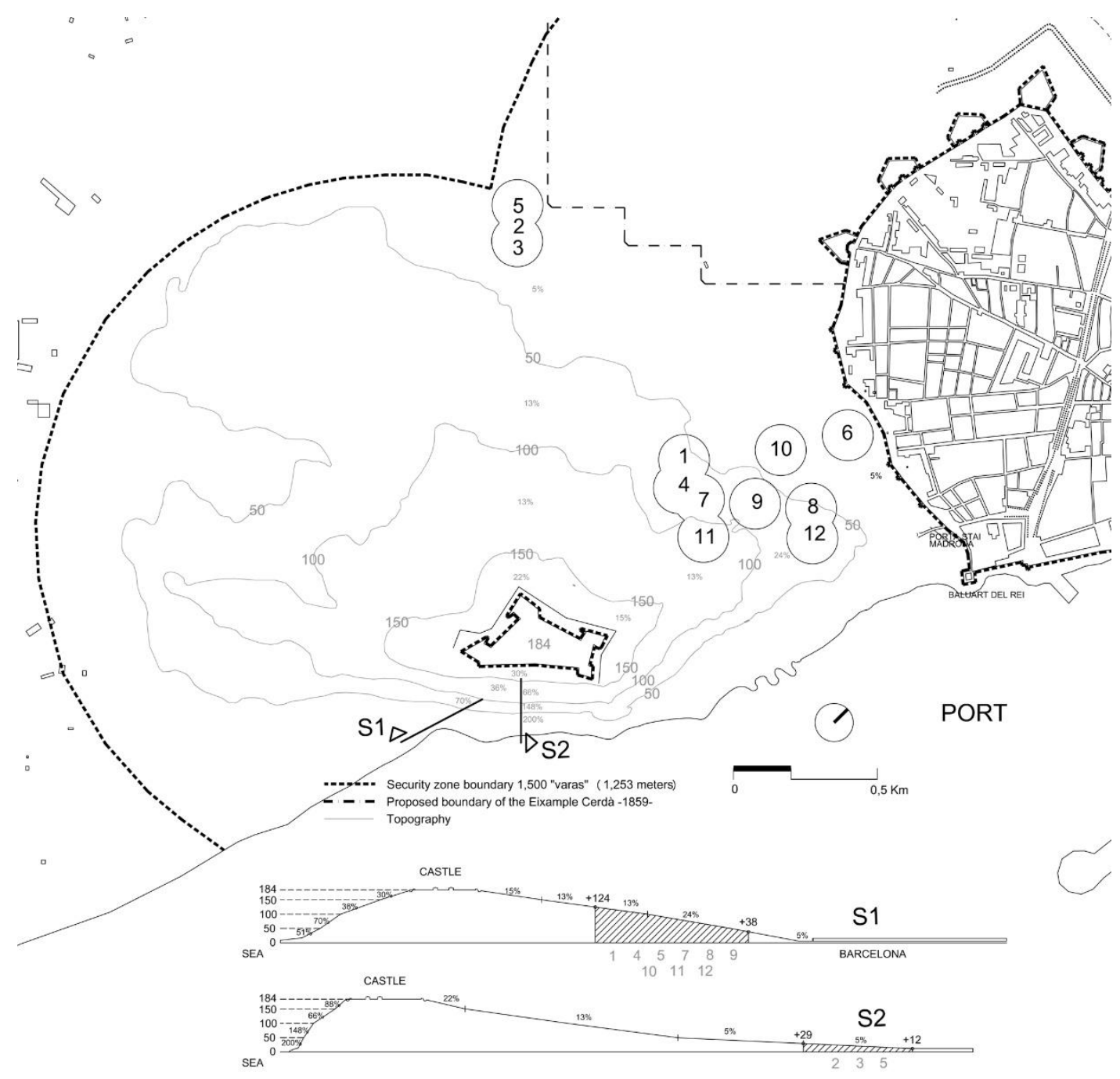

Fig 2. Topographic study of Mount Montjuïc concerning the settlements studied (1-12).

(Drawing by R. Ripoll, private archive, 2019)

The adaptation of the proposed developments is seen to be carried out topographically- and cadastrally-speaking on two different levels. An initial adaptation arises from the preservation of the original irregular property boundary and, therefore, the implementation of compensation mechanisms with neighbouring properties to realign the perimeters and adapt them to the regular delimitation lines of the proposed planning are not observed (Fig. 3). These cadastral irregularities, despite representing an objective loss of land use, introduces a morphological uniqueness and richness. Pre-existing perimeters that may be conceptualized as urban accidents, functionally negative, but positive in terms of landscape, with a direct impact when defining both the streets and open spaces and the arrangement of the plots. This involves a second aspect of adaptation that directly relates the forms of urban planning with the forms of the landscape. Without doubt, this morphological adaptation requires seeking the places with the gentlest gradients both in the intermediate developments as far as the number of dwellings is concerned (examples 6 to 8) and in the larger housing estates (examples 9 to 12). 


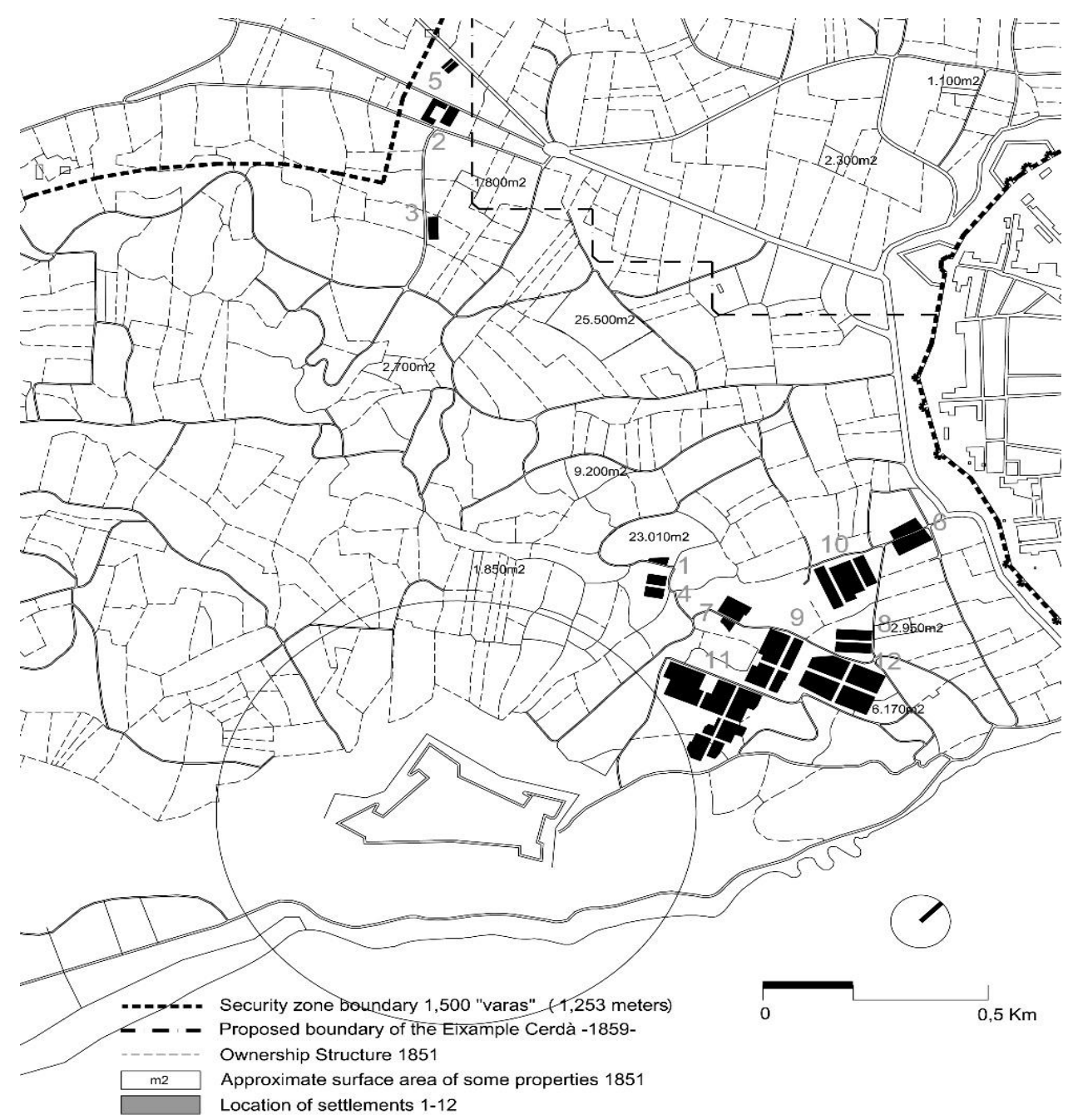

Fig 3. Cadastral study of Mount Montjuïc concerning the settlements studied (1-12).

(Drawing by R. Ripoll, private archive, 2019)

\section{MORPHOLOGY AND INTEGRATION IN THE LANDSCAPE}

The first thing noticed is the little time required for the granting of the permits for the studied works (between 1864 and 1868). This relatively short period, in the case of the examples studied, led to the construction of 466 single-family houses in little time. This resulted in both typological systematization (similar types) and constructive rationalization (traditional construction). This influenced the creation of single-family houses set in a row, usually formed by a structural bay with cross ventilation and arranged in most cases with the street on one side and the courtyard or garden on the other. Such architectural typology requires the creation of rectangular parcels ranging from 28 $\mathrm{m} 2$ (example 5) to $288 \mathrm{~m} 2$ (example 12). This in turn imposed the arrangement of facades of a width of between $4.4 \mathrm{~m}$ (example 5) and $6 \mathrm{~m}$ (examples 7, 9 and 12). The other urban parameters are characteristic of low-density single-family dwellings (occupation fluctuates around $60 \%$, the floor area ratio of $0.6 \mathrm{~m} 2 / \mathrm{m} 2$, and height is less than $3 \mathrm{~m}$ ). 
It should be noted that the key feature of these dwellings is their autonomy of services, such as their individual toilet (commonly located at the exit of the rear courtyard), the drinking water well (also mainly found in the courtyard), the sink, tank or pond for watering (always located beside the well), and finally the enclosed patio/garden (located behind the house) (Table 2).

Table 2.

Urban parameters of the types of architecture.

\begin{tabular}{|c|c|c|c|c|c|c|c|c|c|c|c|c|c|c|c|c|}
\hline \multicolumn{7}{|c|}{ GENERAL ASPECTS } & \multicolumn{10}{|c|}{ URBAN PARAMETERS } \\
\hline & 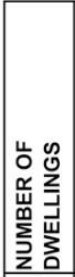 & 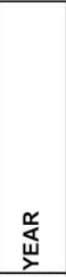 & \begin{tabular}{|l} 
舀 \\
zo \\
\end{tabular} & $\begin{array}{l}\text { 으 } \\
\text { 은 } \\
\text { d } \\
\end{array}$ & 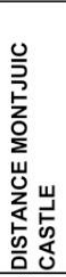 & 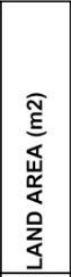 & 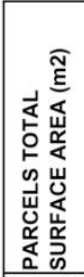 & 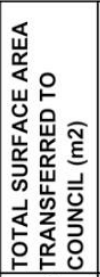 & 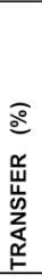 & 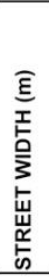 & 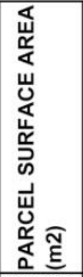 & 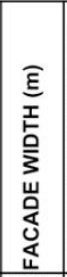 & 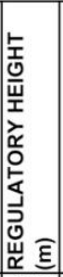 & 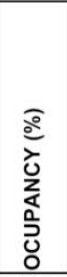 & 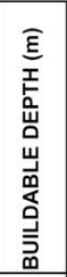 & 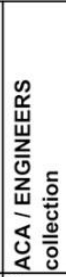 \\
\hline 1 & 6 & 1865 & $\begin{array}{l}\text { VALLCORBA, } \\
\text { Pau }\end{array}$ & $\begin{array}{l}\text { Cami Creu de } \\
\text { Molers }\end{array}$ & $\begin{array}{c}\text { 3rd } \\
\text { zone }\end{array}$ & 533 & $77-120$ & 0 & 0 & 1 & $77-120$ & $\begin{array}{c}6.3 \text { to } \\
10 \\
\end{array}$ & 3,5 & $\begin{array}{c}67 \\
\text { to } 85\end{array}$ & $\begin{array}{c}6 \\
\text { to } 15 \\
\end{array}$ & $\begin{array}{l}\text { file } \\
53 / 13 \\
\end{array}$ \\
\hline 2 & 22 & 1865 & $\begin{array}{l}\text { BONAFONT, } \\
\text { Esteve }\end{array}$ & \begin{tabular}{|l|} 
Carrer \\
Princesa
\end{tabular} & 1390 & 2661 & 133 & 769 & 29 & I & 133 & 5,6 & 3,5 & 48 & 13 & file 57 \\
\hline 3 & 11 & 1864 & $\begin{array}{l}\text { BONAFONT, } \\
\text { Joan }\end{array}$ & $\begin{array}{l}\text { 3rd zone of } \\
\text { the Castle }\end{array}$ & $\begin{array}{c}\text { 3rd } \\
\text { zone }\end{array}$ & 1155 & 105 & 0 & 0 & 1 & 105 & 5 & 3 & 45 & 9 & file 57 \\
\hline 4 & 16 & 1865 & $\begin{array}{l}\text { VALLCORBA, } \\
\text { Pau }\end{array}$ & $\begin{array}{l}\text { Cami Creu de } \\
\text { Molers }\end{array}$ & $\begin{array}{c}\text { 3rd } \\
\text { zone }\end{array}$ & 2508 & 134 & 0 & 0 & 8 & 134 & 5,6 & 3,5 & 68 & 16 & $\begin{array}{l}\text { file } \\
53 / 13\end{array}$ \\
\hline 5 & 21 & 1864 & $\begin{array}{l}\text { GASET, } \\
\text { Miquel }\end{array}$ & $\begin{array}{l}\text { Hostafrancs } \\
\text { district }\end{array}$ & 1450 & 826 & 28 & 171 & 21 & 4 & 28 & 4,4 & 3 & 100 & 6,1 & file 20 \\
\hline 6 & 27 & 1867 & $\begin{array}{l}\text { VILA, } \\
\text { Domenec }\end{array}$ & $\begin{array}{l}\text { Hortes d'en } \\
\text { Bertran }\end{array}$ & 1150 & 4789 & $\begin{array}{c}126 \\
\text { to } 263\end{array}$ & 352 & 7 & 5 & $\begin{array}{c}126 \\
\text { to } 263\end{array}$ & 5,6 & 3,5 & $\begin{array}{c}33 \\
\text { to } 57\end{array}$ & 12,5 & file 55 \\
\hline 7 & 24 & 1868 & $\begin{array}{l}\text { RACIONERO, } \\
\text { Joan }\end{array}$ & $\begin{array}{l}\text { Cami de la } \\
\text { Font Trobada }\end{array}$ & 870 & 4083 & 132 & 1399 & 34 & 9 & 132 & 6 & 3,15 & 52 & 11,5 & $\begin{array}{l}\text { file } \\
40 / 9\end{array}$ \\
\hline 8 & 30 & 1866 & $\begin{array}{l}\text { VALLCORBA } \\
\text { Pau }\end{array}$ & $\begin{array}{l}\text { Cami de la } \\
\text { Font Trobada }\end{array}$ & 850 & 4383 & 125 & 635 & 15 & 8,2 & 125 & 5,2 & 3,5 & 69 & 16,2 & file 53 \\
\hline 9 & 62 & 1867 & $\begin{array}{l}\text { RACIONERO, } \\
\text { Joan }\end{array}$ & $\begin{array}{l}\text { Cami de la } \\
\text { Font Trobada }\end{array}$ & 810 & 13186 & 120 & 4520 & 34 & 10 & 120 & 6 & 3,15 & 59 & 11,5 & $\begin{array}{l}\text { file } \\
42 / 23\end{array}$ \\
\hline 10 & 64 & 1866 & $\begin{array}{l}\text { CARIBAL, } \\
\text { Joan and Josep }\end{array}$ & $\begin{array}{l}\text { 3rd zone of } \\
\text { the Castle }\end{array}$ & 800 & 11464 & 144 & 1785 & 16 & 8 & 144 & 5,8 & 3,1 & 55 & 13,5 & $\begin{array}{l}\text { file } \\
20 / 11\end{array}$ \\
\hline 11 & 87 & 1867 & $\begin{array}{l}\text { CARIBAL, } \\
\text { Joan and Josep }\end{array}$ & $\begin{array}{l}\text { Cami de la } \\
\text { Font Trobada }\end{array}$ & 800 & 16859 & 139 & 3304 & 20 & 10 & 139 & 5,8 & 3,1 & 49 & 12 & $\begin{array}{l}\text { file } \\
18 / 14\end{array}$ \\
\hline 12 & 96 & 1867 & $\begin{array}{l}\text { PADROL, } \\
\text { Francesc }\end{array}$ & $\begin{array}{l}\begin{array}{l}\text { 3rd zone of } \\
\text { the Castle }\end{array} \\
\end{array}$ & 810 & 28522 & $\begin{array}{c}144 \\
\text { to } 288 \\
\end{array}$ & 9343 & 33 & 8 & $\begin{array}{c}144 \\
\text { to } 288 \\
\end{array}$ & 6 & 3,1 & $\begin{array}{c}25 \\
\text { to } 50\end{array}$ & 12 & $\begin{array}{l}\text { file } \\
34 / 4 \\
\end{array}$ \\
\hline
\end{tabular}

This approach involves a strong link between the dwelling and the natural environment and its main elements (sun, air, water and vegetation). This relationship is especially realized through the street, relatively well-proportioned by the height of the buildings, with widths ranging from $4 \mathrm{~m}$ (example 5), $8 \mathrm{~m}$ (examples 4, 7, 8,10 and 12) and up to $10 \mathrm{~m}$ (examples 9 and 11); as well as through spacious courtyards of more than $50 \mathrm{~m} 2$ (examples $3,6,7,9,10,11$ and 12).

The study of the integration of urban planning and landscape was performed using the relationship between: situation, morphology, natural geography and disperse development of each of the examples. A relational study that enables verifying the high level of regional implementation (before and after construction), that measures visually the integration of planning proposals with the reality of the landscape (Fig. 4). A clear comparative picture that enables drawing conclusions, despite being partial and limited, between disperse urban development (with a strong social component) and the fragmented landscape (with a strong natural component) near Mount Montjuïc in Barcelona during this period. 
1
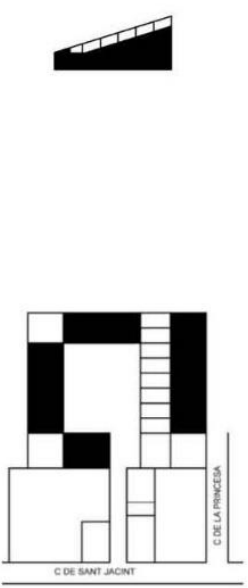

2
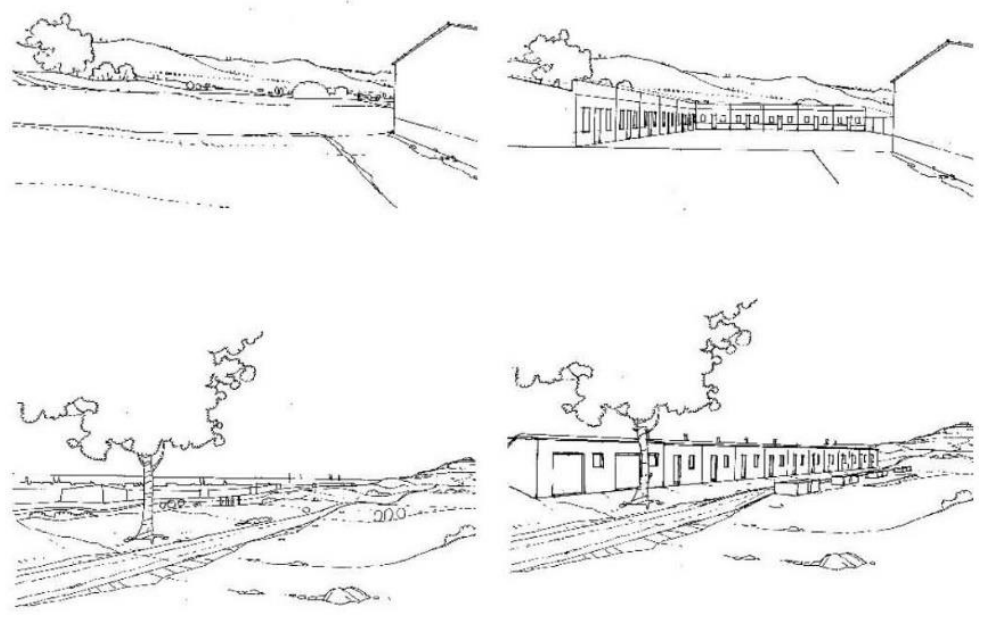

3

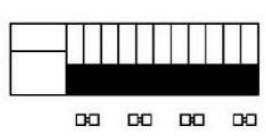

4
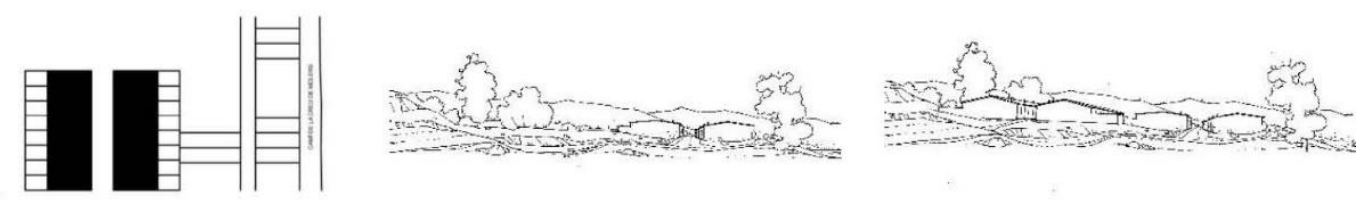

5

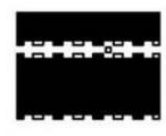

6

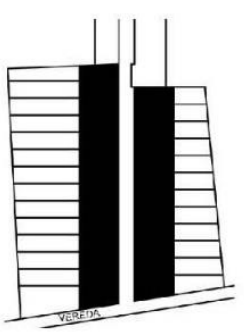

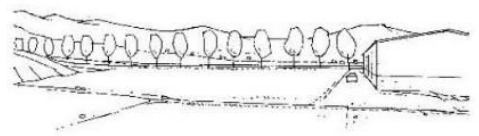
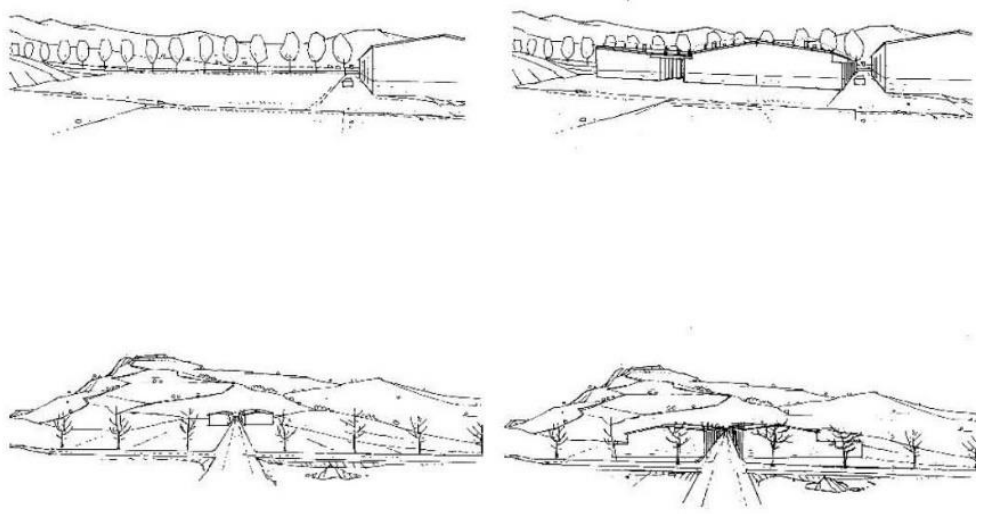

Fig 4. Examples of disperse urban development and its relationship between urban morphology and natural geography (1-6). (Drawings by R. Ripoll, private archive, 2019). 

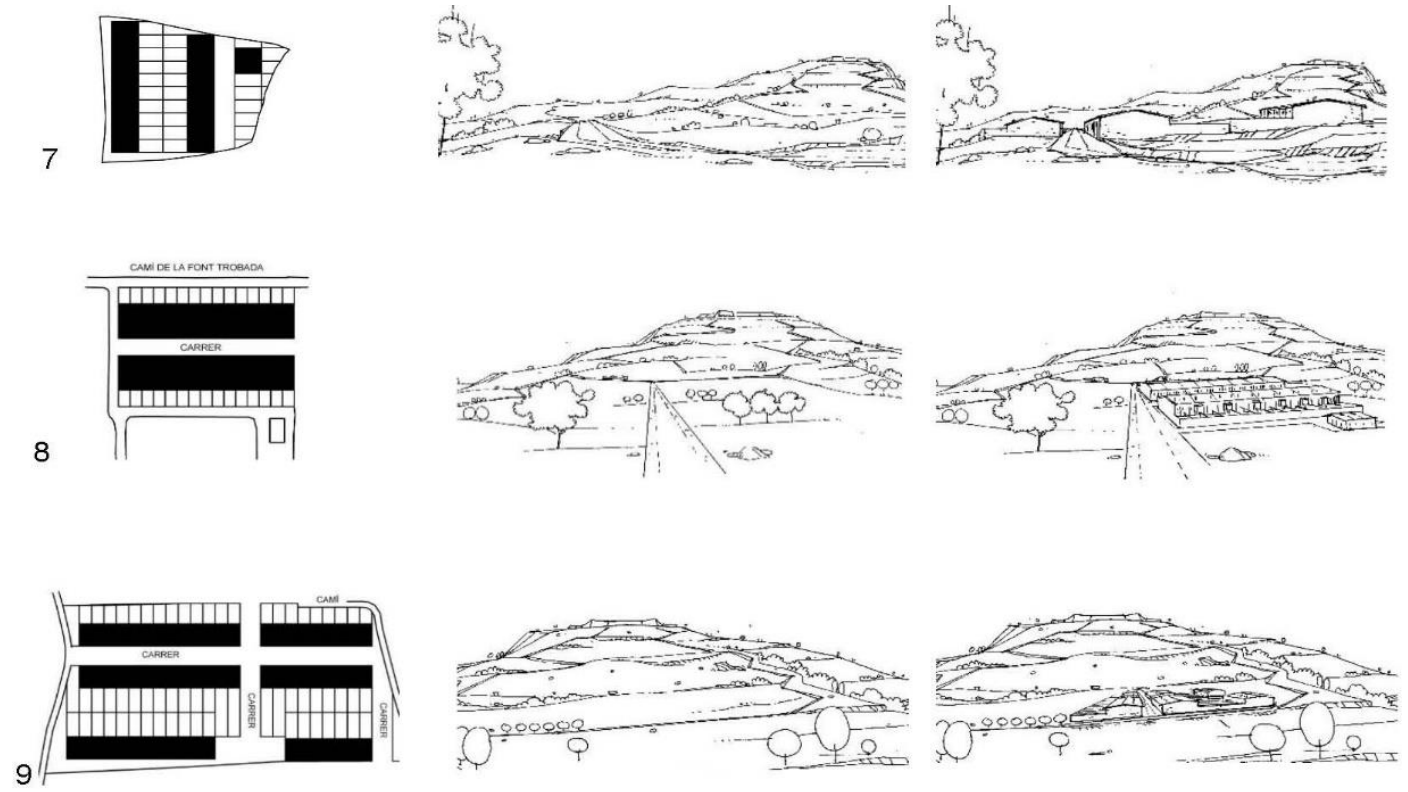

10
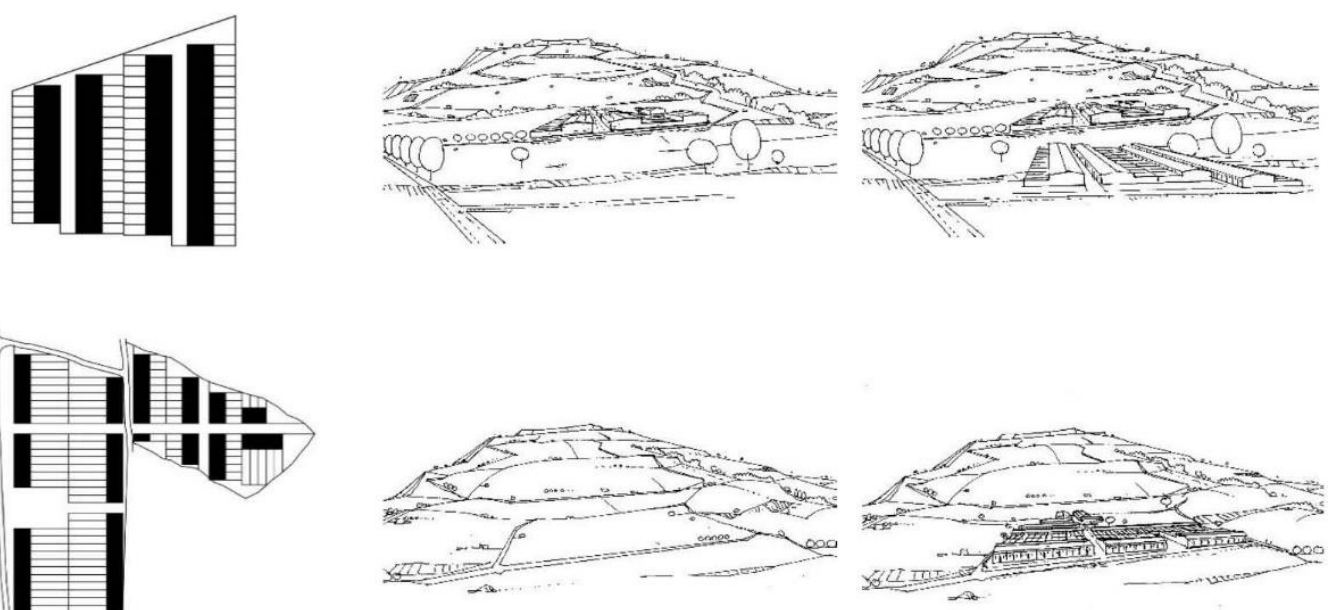

11

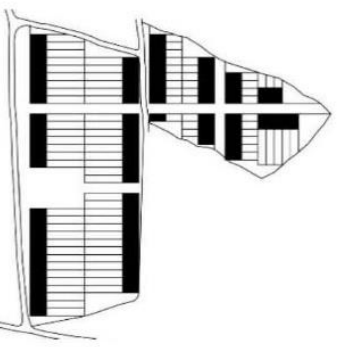

12

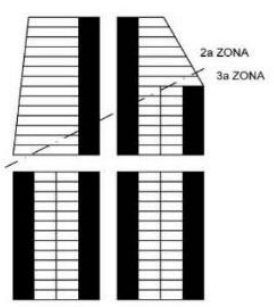

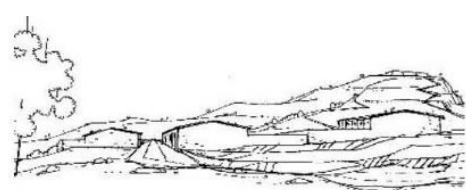

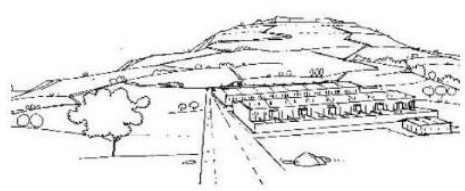

Fig 4. Examples of disperse urban development and its relationship between urban morphology and natural geography (7-12). (Drawings by R. Ripoll, private archive, 2019). 


\section{CONCLUSIONS}

Following the analysis conducted according to the documentation provided, the clear social and cultural potential of disperse urban planning can be deduced, provided that it establishes a close relationship with the natural geography. This hypothesis has been verified in the topographical and geographical adaptation between the different residential groups studied (urban development projects) and Mount Montjuïc (natural environment). The result is not so much a series of marginal suburban developments with respect to the city, but rather a set of small-sized residential centres, integrated into the privileged natural landscape (humanizing), enjoying good views (raised), constant ventilation (dry), and suitable orientation (sunny). Also evident is the complementarity of this duality (city and countryside) which started to be investigated and defined, with all kinds of attempts, during the second half of the nineteenth century, involving projects of the industrial city that intensively bring families to the rural environment. Such projects in other eras were reserved for the rich, becoming increasingly accessible to citizens in general and to factory workers in particular (factories and workshops of the port of Barcelona and the "Poble Sec" district).

We certainly know that the theorizing of the garden city was carried out at the end of the nineteenth century in the project of the town of Letchworth, in the county of Hertfordshire, England, work of the architect Ebenezer Howard (1850-1928), taking place mainly during the twentieth century (Bosma et al., 1997). But it is also true that it arose thanks to multiple antecedents, throughout the second half of the nineteenth century, which are essential for establishing the proposed new relationship between urban and rural geography. Such a background consists of a series of developments of houses linked with the landscape, like the ones in our study, that are essential to begin to popularize some of the benefits of joining the city and the countryside, both in the social imaginary (popular imagery) and in the management of new ways of living in the contemporary world (achievable utopias).

\section{R E F E R E N C E S}

ACA: Archive of the Crown of Aragón. Engineers collection. Barcelona: Files 3 to 57.

Benevolo, L. (1977). Diseño de la ciudad 5. El arte y la ciudad contemporánea. Barcelona: Editorial Gustavo Gili.

Bosma, K., Hellinga, H. (1997) Mastering the City: North-European City Planning 1900- 2000. Rotterdam: NAi Publications

Cassassas, Ll. (1977). Barcelona i l'espai català. Barcelona: Editorial Curial.

De Castro, C. (1997). Geografia en la vida cotidiana. De los mapas cognitivos al prejuicio regional. Barcelona: Ediciones del Serbal.

Capell, H. (2001). Dibujar el mundo. Borges, la Ciudad y la geografia del siglo XXI. Barcelona: Ediciones del Serbal.

Cerdà, I. (1968). Teoria general de la urbanización. Reforma y ensanche de Barcelona. Barcelona: Ediciones Ariel i Editorial Vicens Vives.

Choay, F. (1976). El urbanismo. Utopias y realidades. Barcelona: Editorial Lumen.

García Vázquez. C. (2016). Teorias e historia de la ciudad contemporània. Barcelona: Editorial Gustavo Gili.

González Moreno-Navarro, A. (2008). El camp d'en Grassot, família i territori. Barcelona: Editorial Costa llibreter

Julián, I. (1988). L’urbanisme a Barcelona entre dues exposicions (1888-1929). Barcelona: Els llibres de la frontera.

Rowe, C., Koetter, F. (1998). Ciudad collage. Barcelona: Editorial Gustavo Gili.

Solà-Morales, M. (1994). Les formes de creixement urbà. Barcelona: Edicions UPC.

Serra, E. (1995). Geometria i projecte del sòl als orígens de la Barcelona moderna. La vila de Gràcia.

Barcelona: Edicions UPC.

Sica, P. (1970). La imagen de la Ciudad. De Esparta a Las Vegas. Barcelona: Editorial Gustavo Gili. 